AUTHOR:

Dr Edwin Darrell de Klerk ${ }^{1}$

Prof June Monica Palmer²

AFFILIATION:

${ }^{1}$ Sol Plaatje University, South Africa

${ }^{2}$ Central University of

Technology, South Africa

DOI: http://dx.doi. org/10.18820/2519593X/pie. v40.i1.5

e-ISSN 2519-593X

Perspectives in Education

2022 40(1): 80-95

PUBLISHED:

04 March 2022

RECEIVED:

10 August 2021

ACCEPTED:

23 October 2021

\section{Technology inclusion for students living with disabilities through collaborative online learning during and beyond COVID-19}

\begin{abstract}
Technology-based platforms in higher education institutions (HEls), including online learning, require innovative approaches to ensure inclusive and transformative educational spaces for students living with disabilities. Achieving social equality, technology access and inclusion may contribute to ensuring a seamless instructional design for students living with disabilities in HEls amid and beyond COVID-19. COVID-19 has obliged HEls to adopt alternatives to learning and teaching, making the use of open distance learning $(O D L)$ amid the pandemic more relevant. This theoretical paper considers the significance of ODL by demonstrating how to achieve technology inclusion for students living with disabilities through collaborative online international learning (COIL). Situated within the collaborative learning theory, this paper offers a disability perspective to learning in HEls, through an analysis of stipulations in the Strategic Policy Framework on Disability for the Post-School Education and Training System (2018). The findings indicate that the application of COIL for students living with disabilities may transform their learning experiences and unlock new pathways for their development. The paper recommends that COIL may be used as a response to ensuring access and inclusive education provision for students living with disabilities in HEls.
\end{abstract}

Keywords: Collaborative online international learning; COVID-19 pandemic; inclusive technologies; open distance learning; strategic policy framework on disability; students living with disabilities.

\section{Introduction}

The COVID-19 pandemic necessitated that HEls migrate from conventional face-to-face approaches to exclusively online methods of learning and teaching. Thus, emphasis shifted to the execution of distance learning through several technical tools and Internet-based learning systems (Zhou et al., 2020). However, the adjustment from direct to virtual education, is likely to affect students in HEls undesirably, especially those living with disabilities and who might find it challenging to adapt to a different mode of learning. In contrast, not only did the COVID-19 pandemic exacerbate existing educational inequalities, but it has also demanded 
innovative ways for students to collaborate with peers at any time and in any part of the world through learning methods such as COIL (Dhawan, 2020; Liguori \& Winkler, 2020).

COIL is considered a learning system that promotes virtual collaboration on a mutually beneficial project between students (and lecturers) from two geographically and culturally distinct areas (Appiah-Kubi \& Nichwitz, 2020). This virtual mobility creates a socially varied computer-generated setting for online collaboration where students can enhance and explore their personal abilities as well as develop their intercultural proficiency skills (Rubin, 2015).

Appiah-Kubi and Annan (2020) investigated the participation of engineering technology students from Ghana and the University of Deyton, respectively in an 8-week COIL programme, who differed in terms of language, culture and geographical regions. In this comparative study the students from the respective universities recounted that the teamwork was either effective or remarkably effective. Similarly, King de Ramirez (2021) explored a COIL project among campus students, registered in HEls, situated in the Arizona-Sonora Megaregion. The results indicated that students revealed international citizenship abilities such as the capacity to analyse intercontinental associations as well as global interconnectedness.

Notwithstanding the fact that the above studies made contributions to university students' ability to participate in COIL activities, the current study focuses on advancing COIL and technology inclusion for students living with disabilities, during and beyond the pandemic. In this regard, UNESCO proposes that, "[n]etworking among universities and institutions of higher learning in developed and developing countries should be promoted" (1994:28). When HEls would develop the skills of students living with disabilities, they may be in a position to offer a desirable environment for participation and achievement at an international level. The central question that this paper addresses is: How may HEls achieve technology inclusion for students living with disabilities through collaborative online international learning (COIL) during and beyond COVID-19?

In an attempt to provide answers to the aforementioned question to offer a disability perspective to learning in HEls, we analysed stipulations in the Strategic Policy Framework on Disability for the Post-School Education and Training System (Republic of South Africa [RSA], 2018). An analysis of the indicated policy may be deemed relevant because it provides direction in terms of the enhancement of admission to and accomplishment in postschool education and training for individuals living with disabilities. Furthermore, through an implementation of this strategic policy framework, redress and transformation with respect to inclusion of individuals living with disabilities may be enhanced (RSA, 2018).

\section{Inclusive and transformed spaces in higher education}

In what ways do HEls attempt to render inclusive and transformed spaces to include all students in academic activities? Ashwin and Case (2018) note that such a question enjoys urgent attention internationally, because of its purpose to invite thoughts regarding inclusivity and transformation as tools to develop more understanding about students living with disabilities.

Although the meaning of inclusive has been entrenched in the thoughts of many to refer to individuals with learning, physical and/or sensory challenges, it should, however, not exclude individuals who experience obstacles due to a low socio-economic standing or poverty, among others (Maghuve, 2015). This is regarded as the social model of inclusivity, which stands in contrast to the medical model (Art Beyond Sight, 2014). First, the social model supports 
the view that while sensory, physical, psychological and intellectual dissimilarities may cause personal practical constraint or deficiencies, the latter aspects do not necessarily lead to disability except if society fails to take reason for and embrace individuals notwithstanding their discrete differences. Secondly, the medical model describes a disability as the consequence of a physical circumstance, which is inherent to the individual and which may decrease the individual's value of life and cause strong difficulties to the individual. Considering the aforementioned explication of the social and medical models, the White Paper on Disabilities confirms that inclusivity involves, "a paradigm shift away from the specialness of people to...a wide range of individual differences and needs" (Department of Social Development [DSD], 2016: 22). Interpreting the latter views from an Arendtian perspective, a focus on inclusivity calls for action to put education first. This implies that education does not exist to remedy what is wrong with the world, however unjust or exclusive, but that individuals should be provided with opportunities to practise thinking about the art of being, whilst judging their relationship with others (Korsgaardt, 2016). In HEls, the role of education should thus be to provide equal opportunities and fostering a sense of belonging so that students (also students living with disabilities) experience, "a level of supportive energy and commitment from others so that you can best fully participate in society with no restrictions or limitations" (DSD, 2016: 8). In so doing, students living with disabilities may be able to pursue activities independently with necessary support to enable them to make decisions that may positively affect their lives. When HEls focus on establishing such spaces, inclusivity may be recognised as a moral and transformable act. Whilst inclusivity as a moral act suggests that, "all children are worth educating, that all children can learn" (Rouse \& Florian, 2012: 10), transformability implies that, "human beings are capable of extending and widening their meaning horizons in significant ways" (Murdoch et al., 2020: 668).

Moreover, to widen meaning horizons, the classroom, curriculum knowledge production and information sharing should be geared towards transformed spaces in HEls (Osman, Ojo \& Hornsby, 2018) where equal opportunities and transformative learning are promoted. Howlett, Ferreira and Blomfield (2016) posit that transformative learning may stimulate students to seriously interrogate and reflect on their principles and assumptions, because "learning happens all the time and everywhere; heavily supported by technology and the ease of access to resources that it provides...to create flexible, and multipurpose spaces" (Goria \& Guetta, 2020: 7). To illustrate (in terms of students living with disabilities), Murdock et al. (2020) refer to Jean-Jacques Rousseau's Emile, specifically to a consciousness of learning in the territory of intelligence awareness that unavoidably embraces Emile's personal physical effort to reach new objects, such as a ball (as opposed to the ball being brought to Emile by the teacher), to gain an understanding of his world.

In the aforementioned example, the use of "physical effort" may, for instance, be associated with the struggles students living with disabilities might experience, especially when they are, "denied access to full participation" (DSD, 2016: 4). Therefore, it is imperative that HEls transform existing spaces through Assistive Technology (AT) and inclusive learning technologies with a universal design for learning features into flexible and inspiring areas where students living with disabilities may learn to appreciate new experiences, consider such experiences, whilst taking action to rethink knowledge, ability and beliefs (English, 2016). Being cognisant about new experiences, HEls would be positioned to enable students living with disabilities to negotiate their skills in different places of interaction with other individuals or whilst engaging with technology. 


\section{Technology inclusion for students living with disabilities}

Dikusar (2018) asserts that technology increases the independence of students living with disabilities, freeing them from the continuous need for uninterrupted teacher involvement. Consequently, students have a choice regarding the rapidity of learning that is suitable for them that may lead to more tailored learning. Arguably, an implementation of technologies may allow simplifying communication and increase educational abilities of students living with disabilities. It is worth mentioning that technology inclusion for students living with disabilities aligns with the 2030 Sustainable Development Goal 4 of the United Nations (UN), which pursues to "ensure inclusive and equitable quality education and promote lifelong learning opportunities for all" (UN, 2015: 19-20). The realisation of this goal may help decrease educational inequity for students living with disabilities, specifically during a time such as the COVID-19 pandemic. Thus, to guarantee that logical, continuing solutions are available, policy and legal strategies must be explored (UNESCO, 2020). Emphasising the importance of technology inclusion, Peters contends that,

We stand on the brink of a technological revolution that will fundamentally alter the way we live, work, and relate to one another. In its scale, scope, and complexity, the transformation will be unlike anything humankind has experienced before. We do not yet know just how it will unfold, but one thing is clear: the response to it must be integrated and comprehensive (2017: 28).

The all-inclusive nature of the technology inclusion requires that HEls internationally need to appraise their syllabi so that it would align with competencies and abilities that are necessary for students living with disabilities. The implication that individuals need to learn new skills quickly (Atiku \& Boateng, 2019; Whalley et al., 2021) necessitates that HEls position themselves in such a fashion that students living with disabilities are enabled to increase their capacity to function in these spaces (Cloudebate, 2019). The COVID-19 pandemic has accelerated technology inclusion in HEls, intensifying the digitalisation of human collaboration and virtual education, among others. As such, HEls should find mechanisms to mitigate challenges pertaining to technology inclusion by increasing the use of digital technology, whilst sharpening the skills and capabilities of students living with disabilities (Daskal \& Sherman, (2020; World Economic Forum, 2021)

We contend that technology has proven to be a useful and necessary tool to ensure that HEls continue to provide essential academic services to students living with disabilities during the COVID-19 crisis. Within this context, technology inclusion may profoundly influence the lives of students living with disabilities and ensure that they have access to information and communication with their international counterparts.

\section{Advancing open distance learning through collaborative online international learning}

UNESCO (2016) mentions that it is imperative to guarantee that inclusive education for students living with disabilities is possible through access to education. Although UNESCO (2016) argues for an all-encompassing education for students living with disabilities, the situation regarding open distance learning (ODL) differs in many countries around the world. For instance, China, with a robust scientific organisation, is prosperous in providing ODL, but countries, such as Mongolia and Vietnam are not so successful, due to weak Internet systems (World Bank, 2020). Globally, the quick transition to ODL during COVID-19 provided 
stability to learning processes, but also intensified education inequalities among students, especially those with a poor economic status, as well as those living with disabilities, among others (Aristovnik et al., 2020). Considering that the pandemic might continue for a lengthier period than anticipated, this situation will force HEls to be prepared and equipped with the necessary tools to support students, especially those living with disabilities. Notably, even before COVID-19, it was acknowledged that students internationally did not have equal opportunities relating to access to equipment such as the Internet, tablets and computers (Yazcayir \& Gurgur, 2021).

The challenge with ODL has always been an absence of clear information and the intricacy of the work as well as the study environment of students (Zhang et al., 2020). On a more positive note, Charles Wedemeyer, who is regarded as the father of American distance education, posits that the fundamental features of ODL comprise, better student answerability, accessible teaching, effective combination of broadcasting and approaches, adaptation to differences including the disabled individuals and a comprehensive variety of start, stop and learn times (Wedemeyer, 1977). Wedemeyer's (1977) view suggests that education should be a collaborative and inclusive practice and, therefore, ODL may be considered a viable option as it accommodates millions of students who can study remotely. Significantly, ODL emphasises the removal of challenges relevant to learning and flexibility of learning provision as well as broadening openness to education for the majority of individuals and people living with disabilities so that the learning process can continue (Angba, 2020).

In an attempt to ensure that students living with disabilities use ODL optimally, this paper suggests that a collaborative approach is key. Stoytcheva (2017) regards a collaborative approach as an active process aimed at encouraging and supporting students to work collaboratively to generate understanding, that is to discover, to search for strategies to transform, and, by so doing, to pursue the theoretical understanding required to solve problems. Considering Stoytcheva's (2017) view and drawing on Esche (2018), this paper argues that COIL may be considered as an effective pedagogy that may support the design of a learning atmosphere for students living with disabilities in distinct geographical locations. Appiah-Kubi and Annan (2020) state that COIL typically comprises an organised collaboration between two or more lecturers from HEls who teach related courses. During collaboration, lecturers are positioned to design a common programme, study material or specific outcomes with a joint experimental knowledge instrument. The experimental learning instrument, as an example of project work, functions as the catalyst for student partnerships (Appiah-Kubi \& Annan, 2020). The lecturers then accept mutual obligation in mentoring the students on forming partnerships.

During a COIL study, conducted in two faculties within HEls in the United States and Mexico City, Marcillo-Gómez and Desilus (2016) explored the comparisons and variances between the two faculties in terms of the challenges of teaching students in two different countries, the effect of students' culture on perceptions and participation and how COIL may provide students with unique academic opportunities. The results revealed that students' perspectives broadened, whilst they learnt how to understand and appreciate the differences and the realities of each student. Mudiamu (2020) asserts that such an example of COIL may be understood as a faculty-driven intervention for internationalisation where all students are afforded opportunities for global learning. 
HEls' commitment to support students living with disabilities to participate in COIL as part of ODL, should focus on fostering technology inclusion so that collaboration can be effective. Ahmed concedes that,

the need to pay attention to the processes of inclusion rather than on the promise of inclusion, which is capable of concealing and extending the exclusionary practices of an institution by giving the impression that those practices are overcome or undone (2012: 183).

Pertinently, HEls should commit to technology inclusion, and move beyond conservatism and intolerance about inclusivity, so that students living with disabilities and their embodied experiences feature as agents for positive collaborative learning (Fernandez, 2021).

Ndlovu (2021) considers AT as ideal for technology inclusion for students living with disabilities. Students living with disabilities frequently experience difficulties with functionality, resultant from their deficiencies, as well as inaccessibility with respect to the social and physical environments they may find themselves in, thereby limiting their functionality. Recognised as a human right, governments around the globe, in Africa and in South Africa, made a commitment to facilitate education by empowering every individual to gain admission to learning (Ndlovu, 2021). Governments and HEls should ensure that AT is available to disabled individuals, because there seems to be a significant disparity across countries in collaboration, in terms of the availability of funds to make online collaboration possible (Hersh \& Mouroutsou, 2015). In this regard, HEls should use existing technologies together with available AT to guarantee that students living with disabilities will be able to participate in COIL. By providing appropriate AT and digital devices, students living with disabilities may have increased access to online learning (Tony, 2019).

\section{Theoretical framework: Collaborative learning theory}

Collaborative Learning (CL) stems from the theory of Vygotsky's (1978) perception of the zone of proximal development, which is grounded on people's capacity to learn how to use socially applicable apparatuses (such as computers) and culturally grounded symbols (such as language and writing). Notably, the zone of proximal development not only addresses cognitive development, but it also makes room for human learning (Vygotsky, 1978). In transitioning this zone to a collaborative learning experience, individuals are afforded opportunities to work with others in broadening their learning experience whilst sharing knowledge, exchanging ideas and solving problems (Omrod, 2012). As such, individuals are afforded a myriad of enriching experiences to explore perspectives that may differ from their own.

The afore-mentioned indication, "to work with others" (Omrod, 2012), resonates with the aim of this paper, which is to outline HEls response to achieving technology inclusion for students living with disabilities through collaborative online international learning during and beyond the pandemic. Fundamentally, CL is part of a social consciousness of information, implying that it is, "a process of negotiation or joint construction of meanings which applies to the whole process of teaching" (Roselli, 2016: 256). Roselli further mentions that such a process, "is not about circumstantial application of group techniques, but the promotion of exchange and participation of each member in order to build a shared cognition" (2016: 256). As such, students are motivated to collaboratively find answers to challenges, through dialogue, instead of remembering accurate answers (Harasim, 2012). 
When students living with disabilities are encouraged to participate in COIL, CL suggests that three aspects should be considered, namely the learning design, learning collaboration and learning environment. The learning setting encompasses apparatuses that can be utilised to simplify the collaborative setting. Razali et al. (2015) state that an available and flexible setting has the potential to positively enhance interaction and collaboration between students. Learning interaction is significant in connecting students with others, whilst being supportive of the relationship between students and lecturers (Razali et al., 2015). For the learning design, lecturers could select applicable collaboration skills, whilst providing students with a variety of learning activities and resources (Kaur, Shiram \& Ravichandran, 2011). We argue that CL is a catalyst for technology inclusion for students living with disabilities, through COIL, during and beyond a pandemic by analysing stipulations in education policy.

\section{The rationale for education policy analysis}

Hartshorne offers a comprehensive description of education policy as, "a course of action adopted by government, through legislation, ordinances, and regulations, and pursued through administration and control, finance and inspection, with a general assumption that it should be beneficial to the country and its citizens" (1999: 5). Interpreting Hartshorne (1999), a phrase such as "a course of action" may suggest that policy signifies a conversational approach and is indicative of practices and actions that refer to wider social improvements of teaching (Ball, 2015). Drawing on Ball (2015), we argue that education policy may consist of collaborating texts that may provide information regarding technology inclusion for students living with disabilities through collaborative online learning during and beyond a pandemic. Reading education policy, "is not just a matter of understanding its educational context or reading it as pronouncements of policy-makers, but rather to bear in mind that the discursive formations they contain... await decoding" (Olssen, Codd \& O’Neill, 2004: 2).

When education policy analysis comes into the picture, reference needs to be made to two dissimilar aspects of policy analysis; that is analysis for policy and analysis of policy (Codd, 1988; Olssen et al., 2004). Analysis for policy involves policy advocacy, aiming at providing policymakers with recommendations and information with reference to the modification or making of authentic policies. Analysis of policies may include an investigation into policy purposes, policy effects and policy content. With the afore-mentioned views (Codd, 1998; Olssen et al., 2004) in mind, this paper relates to the classification of analysis of policy, more precisely to the analysis of stipulations in the Strategic Policy Framework on Disability for the Post-School Education and Training System (RSA, 2018). Initially, an analysis of stipulations in the afore-mentioned policy may provide guidance to HEls to achieve technology inclusion for students living with disabilities through collaborative online international learning during and beyond the pandemic. Significantly, when, "we focus analytically on one policy or one text we forget that other policies and texts are in circulation and the enactment of one may inhibit or contradict or influence the possibility of the enactment of others" (Ball, 1993: 6). Therefore, our intention is to strengthen our analysis by also referring to stipulations in the Salamanca statements and framework for action on special needs education (UNESCO, 1994) and White paper on the rights of persons with disabilities (Department of Social Development [DSD], 2016). 


\section{Analysis of the strategic policy framework on disability for the post- school education and training system (2018)}

The Strategic Policy Framework on Disability for the Post-School Education and Training System (RSA, 2018) is a policy document that gives direction in terms of the enhancement of access to and attainment in post-school education and training (including at private institutions) for people living with disabilities (RSA, 2018). Significantly,

through the implementation of this strategic policy framework, transformation and redress with regard to full inclusion, integration and equality for persons with disabilities in the post-school education and training system, will be accelerated (RSA, 2018: i).

Drawing on the promise of the aforementioned, stipulations in the Strategic Policy Framework on Disability for the Post-School Education and Training System (RSA, 2018) will henceforth be analysed to search for policy perspectives that may provide guidance to HEls to achieve technology inclusion for students living with disabilities. Such policy perspectives relate to COIL in that it may provide opportunities to students living with disabilities to interact with counterparts at international HEls, aiming at developing digital skills and competencies whilst working collectively on subject-specific learning assignments.

We thoroughly scrutinised the strategic policy framework and conducted a pre-analysis of many stipulations that might be relevant to students living with disabilities. We then chose those stipulations we were convinced could be considered strong representatives of technology inclusion for students living with disabilities through COIL. We reread the selected stipulations and extracted particular words and phrases for analysis. In so doing, through analysis, we were able to propose activities that HEls could use to achieve technology inclusion for students living with disabilities through COIL during and beyond COVID-19.

Arguably, through COIL, ODL can be advanced because it, "has become indispensable during the COVID-19 pandemic, during which nearly all traditional academic and student mobility has halted worldwide; indeed, COIL may have found its moment to realize its longimagined potential" (Harris, Se \& McKeown, 2021: 1352).

\subsection{Inclusive and transformed spaces as a basis for COIL}

The Strategic Policy Framework on Disability for the Post-School Education and Training System stipulates that, "[w]e have to have a socially inclusive society that cuts across state boundaries" (RSA, 2018: v); and that, when considered from a disability lens, it is necessary to, "provide optimal opportunities for learning, the creation of knowledge and the development of intermediate to high level skills in keeping with international standards academic and technical quality" (RSA, 2018: 41).

An emphasis on "inclusive", "cuts across state boundaries", "optimal opportunities for learning" and "in keeping with international standards" may directly be aligned with COIL. The COVID-19 pandemic has advanced efforts to make learning, based on international collaboration, more accessible, inclusive and equitable for all students. Such collaboration serves as encouragement to students to move beyond their national identity, in an environmentally friendly and sustainable way (Streeter-Ferrari \& Wanderi, 2021). In ensuring that students living with disabilities are provided equal learning opportunities on an international level, HEls should regard COIL as a focal point of ODL in facilitating information exchange, which would enable interaction and knowledge sharing between students at any time (Zarzycka et al., 
2021). The task of HEls would thus be to create inclusive and transformed learning spaces that provide for an, "aesthetically pleasing, stimulating and culturally inclusive atmosphere that helps promote engagement in learning activities" (Holeton, 2020: n.p.). The creation of such spaces may extend learning outside the walls of HEls and remove some of the limitations enacted on learning, such as space and distance (Howcroft, 2017). This statement (Howcroft, 2017) is confirmed by the notions that, "inclusion and participation are essential to human dignity" (UNESCO, 1994) and for the creation of, "a free and just society inclusive [of] all persons with disabilities" (DSD, 2016: 8). We argue that inclusive and transformed spaces, as a basis for COIL, may ensure that students living with disabilities feel respected and valued for who they are, enabling them to fully participate with others with no restrictions or limitations.

\subsection{Technology inclusion as a prerequisite for COIL}

The incorporation of technology in the learning and teaching of students living with disabilities may result in creating an environment of collaboration, communication and support in and beyond their classes (Al-Kindi \& Al-Suqri, 2017; Awidi et al., 2019). In this regard, the Strategic Policy Framework on Disability for the Post-School Education and Training System accentuates the significance of, "instructing all students through developing flexible classroom materials, using various technology tools, and varying the delivery of information or instruction" (RSA, 2018:23); and it also emphasises, "the use of specialised technology, assistive devices and assistive services geared for people with disabilities" (RSA, 2018:55).

Interpreting notions such as "various technology tools" and "assistive services geared for people with disabilities", it seems that it is required from HEls to deliberately implement, "an integration of high quality, synchronous, in-person learning environments with online technologies to enable students to more rapidly build skills and knowledge asynchronously" (Penprase, 2018:212). HEls should ensure that AT are readily available for students living with disabilities and that it matches with the standards for international collaboration. Notably, AT is made up of rehabilitative, assistive and adaptive technologies, as well as associated services, which are explicitly made or modified to serve as practical support for students living with disabilities (Chukwuemeka \& Samaila, 2020). Similarly, Beelen and Jones (2015) contend that the availability of assistive technology like iPods, IPads and computers may be referred to as an internationalisation at-home activity that supports the unfolding of international perspectives in the curriculum for students living with disabilities. DSD states that AT will, "enable persons with disabilities and learning differences to attain independence" (2016:3). In essence, assistive technology helps students living with disabilities' learning processes become easier, whilst making their collaborative experiences more enjoyable and transformative (Wallace, 2018).

Arguably, COVID-19 has required that HEls changed the way in which learning and teaching were offered and had to obtain innovative technology abilities within short spaces of time. Technology inclusion in HEls amid the pandemic brought substance to a stronger focus on COIL in that, "ODL's popularity has skyrocketed as it offers the optimum solution to the academic stress during this current situation" (Adnan \& Anwar, 2020).

\subsection{Transforming the experiences of students living with disabilities in HEls}

Transformative learning in education necessitates the commitment of HEls in that, "[t]he empowerment of people with disabilities is critical in achieving an equitable and inclusive society" (RSA, 2018:12). HEls should be cognisant that an active role in transforming the 
lives of students living with disabilities may be attained through, "education programmes and practices conducive to critical discourse and creative thinking” (RSA, 2018:38).

Indications such as "empowerment" and "education programmes and practices" may be indicative of HEls' task to offer abilities to students living with disabilities regarding an integration of practice and theory, as well as development of synergic activities in groups, as well as the adoption of critical thinking (Howlett, Ferreira \& Blomfield, 2016; Wooltorton et al., 2015). Such empowerment practices may inspire students living with disabilities not only to gain necessary international learning experiences and intercultural communication abilities, but also help to transform preconceived notions of knowledge and abilities (Ortega-Sánchez et al., 2018; Riauka, 2019). A transformative approach to COIL signifies a, "fundamental change in the way we see ourselves and the world in which we live" (Merriam \& Caffarella, 1999:318). HEls should further fully embrace and respect the experiences of students living with disabilities and afford opportunities to participate in COIL. This may enable them, "to arrive at a tentative best judgement upon which to act until new perspectives are encountered" (Marsick \& Mezirow, 2002: n.p.), whilst they simultaneously learn how to, "reflectively and critically take action" (Marsick \& Mezirow, 2002: n.p.) regarding their transformed frame of reference.

Participation in COIL by students living with disabilities can indeed be regarded as a way to advance ODL because it can generate opportunities to reconsider educational conduits by using international learning initiatives, assisting individuals to have a fresh attitude and innovative techniques of thinking about how they relate to the world.

\section{Conclusion}

This paper endeavoured to answer the question: How may HEls achieve technology inclusion for students living with disabilities through collaborative online international learning (COIL) during and beyond COVID-19? The South African Government's policy instructions are intended to empower individuals with disabilities through skills development, education, training and participation. One possible way to empower students living with disabilities may be through ODL in which HEls make room for inclusive and transformed spaces, learning of students living with disabilities amid the 4IR and through advancing participation in COIL.

Through an analysis of the Strategic Policy Framework on Disability for the Post-School Education and Training System (RSA, 2018), this paper contributes to knowledge by recommending that HEls should consider: the creation of inclusive and transformed spaces as a basis for COIL; regard technology as a prerequisite for COIL as significant and transform the experiences of students living with disabilities. Inclusive and transformed spaces should allow for optimal opportunities for learning through a collaboration and discussion of knowledge between students living with disabilities at any time. An inclusion of technology should be geared towards assisting students living with disabilities to experience international learning processes as accessible and transformative. By transforming their experiences, students living with disabilities may be positioned to transform their communication skills, as well as expand their knowledge and abilities.

This paper supports other findings in the academic literature on COIL. Lakkala et al.'s (2021) study explored and compared the collaborative ways in which students in four schools in Austria, Finland, Lithuania and Poland have been supported in their learning. The study concluded that collaborative action should be regarded as significant in creating inclusive 
spaces to support students. In another study, Kolm et al. (2021) conducted a systematic review on international online collaboration competencies in higher education students. The study found that methods to teach and evaluate international online collaboration are underdeveloped and that professionals should be equipped with knowledge as to how to facilitate global virtual teamwork.

We suggest that future research should focus on the experiences of students living with disabilities regarding COIL, especially in terms of how HEls support them in terms of the creation of inclusive and transformed learning spaces, as well as the inclusion of technology to enable them to participate in virtual teaching and learning opportunities.

\section{References}

Adnan, M. \& Anwar, K. 2020. Online learning amid the COVID-19 pandemic: Students' Perspectives. Online Submission, 2(1): 45-51. https://doi.org/10.33902/JPSP.2020261309

Ahmed, S. 2012. On being included: Racism and diversity in institutional life. Durham: Duke University Press. https://doi.org/10.1515/9780822395324

Al-Kindi, S.S. \& Al-Suqri, M.N. 2017. Mobilizing learning: Using Moodle and online tools via smartphones. International Journal of Knowledge Content Development \& Technology, 7(3): 67-86.

Angba, T. 2020. Enhancing inclusive education through open and distance education for individuals with disabilities in Nigeria. Available at https://www.researchgate.net/ publication/344714748 [Accessed 05 July 2020].

Appiah-Kubi, P. \& Annan, E. 2020. A review of a collaborative online international learning. International Journal of Engineering Pedagogy, 10(1): 109-124. https://doi.org/10.3991/ijep. v10i1.11678

Appiah-Kubi, P. \& Nichwitz, J. 2020. Students' perception of collaborative online international learning. Available at https://strategy.asee.org/students-perception-of-collaborative-onlineinternational-learning [Accessed 30 July 2021].

Aristovnik, A., Keržič, D., Ravšelj, D., Tomaževič, N. \& Umek, L. 2020. Impacts of the COVID-19 pandemic on life of higher education students: a global perspective. Sustain, 12(20): 1-34. https://doi.org/10.3390/su12208438

Art Beyond Sight. 2014. Social and medical models of disability: Paradigm change. Available at http://www.artbeyondsight.org/dic/definition-of-disability-paradigm-change-and-ongoingconversation/ [Accessed 27 September 2021].

Ashwin, P. \& Case, J. (Eds.). 2018. Higher education pathways. South African undergraduate education and the public good. Somerset West, Cape Town, South Africa: African Minds. https://doi.org/10.47622/9781928331902

Atiku, S.O. \& Boateng, F. 2019. Rethinking education systems for the fourth industrial revolution. Available at https://www.researchgate.net/publication/335835069_Rethinking Education_System_for_the_Fourth_Industrial_Revolution [Accessed 05 July 2021]. https:// doi.org/10.4018/978-1-5225-9810-7.ch001

Awidi, I.T., Paynter, M. \& Vujosevic, T. 2019. Facebook group in the learning design of a higher education course: An analysis of factors influencing positive learning experience for students. Computers \& Education, 129:106-121. https://doi.org/10.1016/j.compedu.2018.10.018 
Ball, S.J. 2015. What is policy? 21 years later: Reflections on the possibilities of policy research. Discourse: Studies in the Cultural Politics of Education, 36(3): 306-313. https://doi. org/10.1080/01596306.2015.1015279

Beelen, J. \& Jones, E. 2015. Redefining internationalization at home. In A. Curaj, L. Matei, R. Pricopie, J Salmi \& P Scott (Eds.). The European higher education area. Between critical reflections and future policies (pp. 59-72). New York: Springer.

Chukwuemeka, E.J. \& Samaila, D. 2020. Teachers' perception and factors limiting the use of high-tech assistive technology in special education schools in North-West Nigeria. Contemporary Educational Technology, 11(1): 99-109. https://doi.org/10.30935/cet.646841

Cloudebate, U.J. 2019. Can technology create equality for the disabled? - Have your say. Available at https://businesstech.co.za/news/industry-news/343269/can-technology-createequality-for-the-disabled-have-your-say/ [Accessed 05 July 2021].

Codd, J.A. 1988. The construction and deconstruction of educational policy documents. Journal of Education Policy, 3(3): 235-247. https://doi.org/10.1080/0268093880030303

Daskal, J. \& Sherman, J. 2020. Data nationalism on the rise. The global push for state control of data. Available at https://datacatalyst.org/wp-content/uploads/2020/06/Data-Nationalismon-the-Rise.pdf [Accessed 05 July 2021].

Department of Social Development (DSD). 2016. White paper on the rights of persons with disabilities. Pretoria: Government Printer.

Dhawan, S. 2020. Online learning: A panacea in the time of COVID-19 crisis. Journal of Educational Technology Systems, 49(1): 5-22. https://doi.org/10.1177/0047239520934018

Dikusar, A. 2018. The use of technology in special education. Available at: https:// elearningindustry.com/use-of-technology-in-special-education [Accessed 27 September 2021].

English, A.R. 2016. John Dewey and the Role of the teacher in a globalized world: imagination, empathy, and third voice. Educational Philosophy and Theory, 48(10): 1046-1064. https://doi. org/10.1080/00131857.2016.1202806

Esche, M. 2018. Incorporating collaborative online international learning (COIL) into study abroad courses: A training design. Available at https://digitalcollections.sit.edu/capstones/3096 [Accessed 06 July 2021].

Fernandez, S. 2021. Making space in higher education: disability, digital technology, and the inclusive prospect of digital collaborative making. International Journal of Inclusive Education, 25(12): 1375-1390. https://doi.org/10.1080/13603116.2019.1610806

Fry-Bowers, E.K. 2020. Children are at risk from COVID-19. Journal of Pediatric Nursing, 53: A10-A12. https://doi.org/10.1016/j.pedn.2020.04.026

Goria, C. \& Guetta, L. 2020. Transforming learning spaces for multilingual interaction: the outcomes of a workshop delivered at the 2020 eLearning symposium. Available at https:// files.eric.ed.gov/fulltext/ED607142.pdf [Accessed 04 July 2021]. https://doi.org/10.14705/ rpnet.2020.42.1081

Harasim, L. 2012. Learning theory and online technologies. New York: Routledge. https://doi. org/10.4324/9780203846933 
Harris, J.M., Seo, M. \& McKeown, J.S. 2021. Global competency through collaborative online international learning (COIL). 7th International Conference on Higher Education Advances (HEAd'21), 1351-1358. https://doi.org/10.4995/HEAd21.2021.13080

Hartshorne, K. 1999. The making of education policy in South Africa. Oxford: Oxford University Press.

Hersh, M.A. \& Mouroutsou, S. 2015. Learning technology and disability: Overcoming barriers to inclusion: Evidence from a multi-country study. IFAC-PapersOnLine, 48(24): 083-088. https://doi.org/10.1016/j.ifacol.2015.12.061

Holeton, R. 2020. Toward inclusive learning spaces: Physiological, cognitive, and cultural inclusion and the learning space rating system. Available at: https://er.educause.edu/ articles/2020/2/toward-inclusive-learning-spaces [Accessed 30 July 2021].

Howcroft, D. 2017. Graduates vocational skills for the management accountancy profession: Exploring the accounting education expectation - Performance gap. Accounting Education, 26(2): 459-481. https://doi.org/10.1080/09639284.2017.1361846

Howlett, C., Ferreira, J. \& Blomfield, J. 2016. Teaching sustainable development in higher education. International Journal of Sustainability in Higher Education, 173: 305-321. https:// doi.org/10.1108/IJSHE-07-2014-0102

Kaur, A., Shriram, R. \& Ravichandran, P. 2011. A framework for online teaching and Learning: The S-care pedagogical model. 25th AAOU Annual Conference, 1-12.

King de Ramirez, C. 2021. Global citizenship education through collaborative online international learning in the Borderlands: A case of the Arizona-Sonora Megaregion. Journal of Studies in International Education, 25(1): 83-99. https://doi.org/10.1177/1028315319888886

Kolm, A., de Nooijer, J., Vanherle, K., Werkman, A., Wewerka-Kreimel, D., Rachman-Elbaum, S. \& van Merriënboer, J.J.G. 2021. International online collaboration competencies in higher education students: A systematic review. Journal of Studies in International Education, 2021: 1-19. https://doi.org/10.1177/10283153211016272

Korsgaard, M.T. 2016. An Arendtian perspective on inclusive education. Philosophy of Education Society of Great Britain. Annual Conference (1-3 April 2016). Oxford: Ne College.

Lakkala, S., Galkienè, A., Navaitienè, J., Cierpiałowska, T., Tomecek, S. \& Uusiautti, S. 2021. Teachers supporting students in collaborative ways-an analysis of collaborative work creating supportive learning environments for every student in a school: Cases from Austria, Finland, Lithuania, and Poland. Sustainability, 13: 2804. https://doi.org/10.3390/su13052804

Liguori, E.W. \& Winkler, C. 2020. From offline to online: Challenges and opportunities for entrepreneurship education following the COVID-19 pandemic. Entrepreneurship Education and Pedagogy, 3(4):346-351. https://doi.org/10.1177/2515127420916738

Maguvhe, M. 2015. Inclusive education: A transformation and human rights agenda under spotlight in South Africa. African Journal of Disability, 4(1): a183. https://doi.org/10.4102/ajod. v4i1.183

Marcillo-Gómez, M. \& Desilus, B. 2016. Collaborative online international learning experience in practice opportunities and challenges. Journal of Technology Management \& Innovation, 11(1): 30-35. https://doi.org/10.4067/S0718-27242016000100005 
Marsick, V. \& Mezirow, J. 2002. New work on transformative learning. Available at: http://www. tcrecord.org [Accessed 30 July 2021].

Merriam, S. \& Caffarella, R. 1999. Learning in adulthood, second edition. San Francisco: Jossey Bass.

Mudiamu, S.S. 2020. Faculty use of collaborative online international learning (COIL) for internationalization at home. Unpublished PhD thesis. Portland: Portland State University. https://doi.org/10.15760/etd.7342

Murdoch, D., English, A.R., Hintz, A., \& Tyson, K. 2020. Feeling heard: Inclusive education, transformative learning, and productive struggle. Educational Theory, 70(5): 653-679. https:// doi.org/10.1111/edth.12449

Ndlovu, S. 2021. Provision of assistive technology for students with disabilities in South African higher education. International Journal of Environmental Research and Public Health, 18: 1-19. https://doi.org/10.3390/ijerph18083892

Olssen, M., Codd, J. \& O’Neill, A. 2004. Education policy: Globalization, citizenship and democracy. London: Sage Publications.

Ormrod, J.E. 2012. Human learning, sixth edition. Upper Saddle River, NJ: Pearson Education.

Ortega-Sánchez, M., Moñino, A., Bergillos, R.J., Magaña, P., Clavero, M., Díez-Minguito, M. \& Baquerizo, A. 2018. Confronting learning challenges in the field of maritime and coastal engineering: Towards an educational methodology for sustainable development. Journal of Cleaner Production, 171(2018): 733-742. https://doi.org/10.1016/j.jclepro.2017.10.049

Osman, R., Ojo, E. \& Hornsby, D.J. 2018. Transforming higher education towards a socially just pedagogy. Journal of Human Behavior in the Social Environment, 28(4): 393-396. https:// doi.org/10.1080/10911359.2018.1476641

Penprase, B.E. 2018. The fourth industrial revolution and higher education. In N.W. Gleason (Ed.). Higher education in the era of the fourth industrial revolution (pp. 207-225). Singapore: Palgrave MacMillian. https://doi.org/10.1007/978-981-13-0194-0_9

Peters, M.A. 2017. Technological unemployment: Educating for the fourth industrial revolution. Journal of Self-Governance and Management Economics, 5(1): 25-33. https://doi. org/10.22381/JSME5120172

Quiamzade, A., Mugny, G. \& Butera, F. 2013. Psychologie Sociale de la Connaissance [Social Psychology of Knowledge]. Grenoble: Presses Universitaires de Grenoble [Grenoble University Press].

Razali, S.N., Shahbodin, F., Hussin, H. \& Bakar, N. 2015. Online collaborative learning elements to propose an online project based collaborative learning model. Jurnal Teknologi [Journal of Technology], 77(23): 55-60. https://doi.org/10.11113/jt.v77.6688

Republic of South Africa. 2018. White paper on the rights of persons with disabilities. Pretoria: Government Printer.

Riauka, E. 2019. The benefits of virtual exchange programs and collaborative online international learning. Available at https://www.universityaffairs.ca/career-advice/globalcampus/the-benefits-of-virtual-exchange-programs-and-collaborative-online-internationallearning/ [Accessed 30 July 2021]. 
Roselli, N.D. 2016. Collaborative learning: Theoretical foundations and applicable strategies to university. Propósitos y Representaciones [Purposes and Representations], 4(1): 219-280. https://doi.org/10.20511/pyr2016.v4n1.90

Rouse, M. \& Florian, L. 2012. Inclusive practice project: Final report. Aberdeen, Scotland: University of Aberdeen.

Rubin, J. 2015. Faculty guide for collaborative online international learning course development. Available at: http://www.ufic.ufl.edu/UAP/Forms/COIL_guide.pdf [Accessed 27 September 2021].

Stoytcheva, M. 2017. Collaborative distance learning: Developing an online learning community. Proceedings of the 43rd International Conference Applications of Mathematics in Engineering and Economics AIP Conf. Proc. 1910, 060009-1-060009-8; https://doi. org/10.1063/1.5014003

Streeter-Ferrari, M. \& Wanderi, J. 2021. Global virtual learning: Wright State collaborative online international learning (COIL).

Tony, M.P. 2019. The effectiveness of assistive technology to support children with specific learning disabilities: Teacher perspectives. Unpublished Master's dissertation. Jönköping, Sweden: Jönköping University.

UNESCO. 1994. The Salamanca statement and framework for action on special needs education. Spain: UNESCO.

UNESCO. 2016. Digital empowerment: access to information and knowledge using ICTs for persons with disabilities. Available at https://unesdoc.unesco.org/ark:/48223/pf0000244543 [Accessed 05 July 2021].

UNESCO. 2020. Empowering students with disabilities during the COVID-19 crisis. Available at: https://bangkok.unesco.org/content/empowering-students-disabilities-during-covid-19crisis [Accessed 27 September 2021].

United Nations (UN). 2015. Transforming our world: The 2030 agenda for sustainable development; A/RES/70/1. New York, NY, USA: United Nations.

Vygotsky, L.S. 1978. Mind in society. Cambridge, MA: Harvard University Press.

Wallace, F. 2018. Assistive technology for students with disabilities. Available at https:// elearningindustry.com/assistive-technology-for-students-disabilities [Accessed 30 July 2021].

Wedemeyer, C.A. 1977. Growth and structure of distance education. London: Croom Helm.

Whalley, B., France, D., Park, J., Mauchline, A. \& Welsh, K. 2021. Towards flexible personalized learning and the future educational system in the fourth industrial revolution in the wake of COVID-19. Higher Education Pedagogies, 6(1): 79-99. https://doi.org/10.1080/23752696.20 21.1883458

Wooltorton, S., Wilkinson, A., Horwitz, P., Bahn, S., Redmond, J. \& Dooley, J. 2015. Sustainability and action research in universities. International Journal of Sustainability in Higher Education, 16(1): 424-439. https://doi.org/10.1108/IJSHE-09-2013-0111

World Bank. 2020. Educational policies in the COVID-19 pandemic: What can Brazil learn from the rest of the world? Available at http://pubdocs.worldbank.org/en/511671585947801777/ EDUCATIONAL-POLICIES-IN-THE-COVID-19-PANDEMIC-WHAT-CAN-BRAZIL-LEARNFROM-THE-REST-OF-THE-WORLD.pdf [Accessed 06 July 2021]. 
World Economic Forum. 2021. The global risks report 2021. 16th Edition. Zurich: World Economic Forum.

Yazcayir, G. \& Gurgur, H. 2021. Students with special needs in digital classrooms during the COVID-19 pandemic in Turkey. Pedagogical Research, 6(1): em0088. https://doi. org/10.29333/pr/9356

Zarzycka, E., Krasodomska, J., Mazurczak-Mąka, A. \& Turek-Radwan, M. 2021. Distance learning during the COVID-19 pandemic: students' communication and collaboration and the role of social media. Cogent Arts \& Humanities, 8(1): 1-20. https://doi.org/10.1080/23311983 .2021 .1953228

Zhang, W., Wang, Y., Yang, L. \& Wang, C. 2020. Suspending classes without stopping learning: China's education emergency management policy in the COVID-19 outbreak. Journal of Risk Financial Management, 13(3): 55. https://doi.org/10.3390/jrfm13030055 [Accessed 06 July 2021]. https://doi.org/10.3390/jrfm13030055

Zhou, L., Li, F., Wu, S. \& Zhou, M. 2020. School's out, but class's on, the largest online education in the world today: Taking China's practical exploration during the COVID-19 pandemic prevention and control as an example. Best Evidence in Chinese Education, 4(2): 501-519. https://doi.org/10.15354/bece.20.ar023 